\title{
Study on the Competitive Force of Car Brands in Market of China
}

\author{
Tianwei Zhao \\ School of Economics and Management, Changchun University of Science and Technology \\ Changchun 130022, China \\ Tel: +86-431-8539-8317Ｅ-mail: zhao-tian-wei@163.com
}

Received: October 12, $2010 \quad$ Accepted: October 29, $2010 \quad$ DOI: 10.5430/ijba.v1n1p80

\begin{abstract}
The strong brands of transnational companies have occupied most shares in the car market of China, with larger profit share. For the brand competitive force, the own-brand enterprises are in the absolutely inferior position. The simple model evaluating the brand competitive force is established in this article, and by the analysis of two Chinese enterprises, the brand competitive index model could reflect the actuality of the car brand competitive force in China, and relative opinions and suggestions are proposed for own-brand enterprises to enhance the brand competitive force.
\end{abstract}

Keywords: Cars, Brand competitive force, Index, Model

In 2009, the car market of China had been the biggest market in the world, and this market would create the new sales record of car in the world. In this market, with the most profit in the world, the strong brands of transnational companies have occupied most shares, with larger profit share. For the brand competitive force, the own-brand enterprises are in the absolutely inferior position. In this article, the simpler brand competitive index model will be established to evaluate the competitive index of the brand, and relative opinions and suggestions are proposed for own-brand enterprises to enhance the brand competitive force.

\section{Design of the brand competitive force evaluation index system}

In numerous car brands of the market of China, five transnational enterprises and two own-brand sate-owned enterprises are selected in this article, and in each enterprises, three cars including the A0 level car, the A level car, and the B level car are selected for the research. The brand competitive index is denoted by A, and the research involves 21 brands.

The brand competitive force of the enterprise embodies the core competitive ability of the enterprise. Except for different ability, the strong brand could also bring durative profitability for the enterprise, and especially, it could help the enterprise to obtain the brand premium ability with excessive profit. Because of the high reputation, the strong brand has the most important character, i.e. the high price. At the same time, the strong brand has longer product line, larger price range, and higher market share.

Following indexes are designed as follows.

(1) Price. $\mathrm{P}$ is the average price of the products, and it is denoted by the mathematic average value of all products' prices of this product line. The prices are all from the direction prices in the official market in the late of Sep of 2010 , and the average prices of these 21 brands products are seen in Figure 1.

(2) Length of the brand product line. $\mathrm{L}$ is the amount of the product items represented by different prices, and relative data come from the official website of enterprises.

(3) Price range. $\mathrm{W}$ is denoted by the result that the minimum price is divided by the maximum price in the product items.

(4) Market share. $\mathrm{R}$ is denoted by the absolute sales of the product, which is accumulated from Jan to Aug in 2010 by the China Association of Automobile Manufacturers.

(5) Brand competitive index. A is computed by many factors such as the product price, the brand product line length, and the price range which could be grasped by the enterprises, and the brand market share, which all influence the brand competitive index.

$\mathrm{A}=(\mathrm{R} * \mathrm{P}) /(\mathrm{L} * \mathrm{~W})$

Where, $\mathrm{R} * \mathrm{P}$ is the approximate sales, which is positively related with A. For single influencing factor, $\mathrm{R}$ is positively related with $\mathrm{A}$, and $\mathrm{P}$ is positively related with $\mathrm{P}$. When the price elasticity is bigger than 1, the depreciating could 
increase the total sales, and here, $\mathrm{R}$ is negatively related with $\mathrm{P}$, but the depreciating will also directly damage the brand value, and the current price discount is temporary promotion, so the relationship between $\mathrm{R}$ and $\mathrm{P}$ will not be studied in this article.

$\mathrm{L} * \mathrm{~W}$ could be the product covering range of the brand, and in certain one concrete market, $\mathrm{L} * \mathrm{~W}$ is bigger, the brand competitive force will be diluted more, so it is negatively related with A.

\section{Quantitative analysis of international brand competitive forces}

The quantitative analysis of the strong brands of transnational companies is mainly to test where the brand competitive index model could reflect the real competitive state of the product.

From Table 2, the sequence of the values of A is CITY, ACCENT, VIOS, POLO, FIESTA, which is same with the sales sequence. In A0 level products, $\mathrm{A}$ is most sensitive to R, because the difference degree of other factors such as $\mathrm{P}, \mathrm{L}$, and $\mathrm{W}$ is not high. The A value of CITY exceeds much higher than the average value, and CITY has the highest brand competitive force, and highest value of $\mathrm{W}$, which is because that the Honda Company has pushed the A0 level high-end product with 1.8L. The A value of ACCENT is near the average value, i.e. 4.89, and from its good sales performance of Hyundai Company, the A value is at the second position, according with the practice. The A, W, and R of Ford FIESTA are minimal in all products, so its brand competitive force is worst. Above conclusion better indicates the competitive situation of A0 level joint-venture car products.

From Table 3, the A value of the A level car product is comprehensively influenced by above four factors. The A values of CIVIC and FOCUS are near the average value 11.48, which basically reflects the brand competitive situation of Honda and Ford. The A value of Hyundai ELANTRA is biggest, which shows that the brand value of Hyundai is promoted quickly in China, and in north America, its brand value is promoted more quickly, and the model could better fit this practice. The A values of CAROLA and SAGITAR are small, and in the practice, their cost performances are not high. Their values of $\mathrm{L}$ are at the first and the second position, and obviously higher than other competitive cars, which "dilutes" their brand competitive forces.

From Table 4, in B level products, A is most sensitive to $\mathrm{P}$, and the ranking of the brand competitive index is same with the average price. $\mathrm{P}$ is positively related with $\mathrm{R}$, which indicates that in the middle and high level car market, the quality of high price determines the market share. The A value of Hyundai SONATA NFC is much lower than other brands, which proves that in the growth of Hyundai Company, the promotion of the brand value is the process that the low-end product gradually diffuses to the high-end product.

Through above analysis, the brand competitive index model could better reflect the practical competitive status of above joint-venture products, and the model is applied to study the own-brand cars of China as follows.

\section{Brand strategies of own-brand-car companies}

\subsection{Jianghuai Company}

From Table 5, the own-brand competitive force has obvious gap with transitional companies, and with the increasing of the product level, the ratio between the A average value of transnational company with the A average value of Jianghuai Company goes up by the geometric series. So the model could better reflect the practical competitive state of Jianghuai Company.

The brand competitive force of Jianghuai A0 level product is higher than Ford FIESTA, and to further enhance the value of A, the first method is to reduce the product line, i.e. reducing the denominator, and the second method is to enhance the sales by depreciating, i.e. increasing the numerator.

For A level product, HEYUE is the new product, and though the price elasticity is bigger than 1, but the price bottom should not be broken, and for this product, to simply adjust single influencing factor is not far enough to enhance the value of $\mathrm{A}$, and to increase the configuration and to improve the product combination should be implemented at the same time.

Because the value of A of the B level BINYUE is too small, new product should be researched and developed on the instant.

\subsection{Chery Company}

From Table 6, after Chery Company successfully pushed the product brands such as A3 and FULWIN 2, its values of A of A0 and A level products are also obviously higher than Jianghuai, and comparing with international big brand, FULWIN 2 is almost at the same competitive state. The difference between A3 and international brands is 2.1 times, and though the value of A of A3 is lower than above five international brands, but it is easy to reduce the gap. For B level 
products of Chery Company, G5 has been the substitute product of EASTAR.

\section{Conclusions}

By the analysis of two China enterprises, their values of A could accord with the practical competition ideally, and the brand competitive index model also could better reflect the practice of the car brand competitive force in the market of China, with certain application value.

\section{References}

Philip, L., and Kevin, L.K.. (2009). Translated by Wang, Hong \& Ying, Bin. Marketing Management. Beijing: Tsinghua University Press. Dec.

Xu, X. (2007). Auto Marketing (2nd Edition). Beijing: Mechanic Industry Press. Feb.

Table 1. Equal prices of 21 brand cars (unit: ten thousand RMB)

\begin{tabular}{|l|l|l|l|l|l|l|l|l|}
\hline No. & Company & \multicolumn{1}{|c|}{ A0 } & $\begin{array}{c}\text { Equal } \\
\text { price }\end{array}$ & \multicolumn{1}{|c|}{ A } & Equal price & \multicolumn{1}{|c|}{ B } & $\begin{array}{c}\text { Equal } \\
\text { price }\end{array}$ & Remark \\
\hline 1 & Toyota & VIOS & 10.36 & CAROLA & 15.67 & CAMRY & 23.26 & \\
\hline 2 & Honda & CITY & 12.00 & CIVIC & 15.19 & ACCORD & 24.02 & \\
\hline 3 & Volkswagen & POLO & 10.09 & SAGITAR & 15.56 & MAGOTAN & 22.71 & \\
\hline 4 & Ford & FIESTA & 9.79 & FOCUS & 12.70 & MONDEO & 20.50 & \\
\hline 5 & Hyundai & ACCENT & 8.93 & ELANTRA & 11.50 & $\begin{array}{l}\text { SONATA } \\
\text { NFC }\end{array}$ & 18.52 & \\
\hline 6 & Jianghuai & TONGYUE & 5.52 & HEYUE & 7.40 & BINYUE & 12.33 & \\
\hline 7 & Chery & FULWIN 2 & 5.78 & A3 & 8.93 & EASTAR & 9.66 & \\
\hline
\end{tabular}

Source: http://db.auto.sohu.com/cxdata/

Table 2. Values of A0 level products

\begin{tabular}{|l|l|l|l|l|l|l|l|l|}
\hline No. & Company & A0 & P & R & L & W & A & Ranking \\
\hline 1 & Toyota & VIOS & 10.36 & 2.8 & 8 & 1.38 & 2.62 & 3 \\
\hline 2 & Honda & CITY & 12.00 & 8.11 & 5 & 1.55 & 12.58 & 1 \\
\hline 3 & Volkswagen & POLO & 10.09 & 2.36 & 7 & 1.43 & 2.38 & 4 \\
\hline 4 & Ford & FIESTA & 9.79 & 1.47 & 7 & 1.37 & 1.50 & 5 \\
\hline 5 & Hyundai & ACCENT & 8.93 & 5.31 & 6 & 1.47 & 5.36 & 2 \\
\hline
\end{tabular}

Source: http://db.auto.sohu.com/cxdata/

Table 3. Values of A level products

\begin{tabular}{|c|c|c|c|c|c|c|c|c|}
\hline No. & Company & A & P & R & L & W & A & Ranking \\
\hline 1 & Toyota & CAROLA & 15.67 & 10.83 & 17 & 1.61 & 6.19 & 4 \\
\hline 2 & Honda & CIVIC & 15.19 & 6.93 & 7 & 1.36 & 11.04 & 2 \\
\hline 3 & Volkswagen & SAGITAR & 15.56 & 7.51 & 10 & 1.39 & 8.4 & 5 \\
\hline 4 & Ford & FOCUS & 12.70 & 5.26 & 5 & 1.40 & 9.54 & 3 \\
\hline 5 & Hyundai & ELANTRA & 11.50 & 15.09 & 6 & 1.30 & 22.24 & 1 \\
\hline
\end{tabular}

Source: http://db.auto.sohu.com/cxdata/ 
Table 4. Values of B level products

\begin{tabular}{|c|c|c|c|c|c|c|c|c|}
\hline No. & Company & A & P & R & L & W & A & Ranking \\
\hline 1 & Toyota & CAMRY & 23.26 & 10.79 & 12 & 1.55 & 13.47 & 2 \\
\hline 2 & Honda & ACCORD & 24.02 & 11.11 & 8 & 1.84 & 18.18 & 1 \\
\hline 3 & Volkswagen & MAGOTAN & 22.71 & 5.08 & 7 & 1.36 & 12.11 & 3 \\
\hline 4 & Ford & MONDEO & 20.50 & 3.33 & 6 & 1.35 & 8.41 & 4 \\
\hline 5 & Hyundai & $\begin{array}{c}\text { SONATA } \\
\text { NFC }\end{array}$ & 18.52 & 1.38 & 9 & 1.47 & 1.93 & 5 \\
\hline
\end{tabular}

Source: http://db.auto.sohu.com/cxdata/

Table 5. Competitive force index of the brand of Jianghuai Automobile Company

\begin{tabular}{|c|c|c|c|c|c|c|c|c|}
\hline Level & Product & $\mathrm{P}$ & $\mathrm{R}$ & $\mathrm{L}$ & $\mathrm{W}$ & $\mathrm{A}$ & $\begin{array}{c}\text { Equal A value of } \\
\text { transnational } \\
\text { companies }\end{array}$ & Ratio \\
\hline A0 & TONGYUE & 5.52 & 2.83 & 7 & 1.180723 & 1.89 & 4.89 & 2.59 \\
\hline A & HEYUE & 7.40 & 1.93 & 6 & 1.288754 & 1.85 & 11.48 & 6.22 \\
\hline B & BINYUE & 12.33 & 0.26 & 5 & 1.685811 & 0.38 & 10.48 & 27.56 \\
\hline
\end{tabular}

Source: http://db.auto.sohu.com/cxdata/

Table 6. Competitive force index of the brand of Chery Automobile Company

\begin{tabular}{|c|c|c|c|c|c|c|c|c|c|}
\hline Level & Product & $\mathrm{P}$ & $\mathrm{R}$ & $\mathrm{L}$ & $\mathrm{W}$ & $\mathrm{A}$ & Jianghuai A & $\begin{array}{c}\text { Equal A } \\
\text { value of } \\
\text { transnational } \\
\text { companies }\end{array}$ & Ratio \\
\hline A0 & FULEIN 2 & 5.78 & 2.11 & 4 & 1.17 & 2.6 & 1.89 & 4.89 & 1.88 \\
\hline A & A3 & 8.93 & 3.18 & 4 & 1.3 & 5.48 & 1.85 & 11.48 & 2.1 \\
\hline B & EASTAR & 9.66 & 0.21 & 5 & 1.33 & 0.31 & 0.38 & 10.48 & 33.81 \\
\hline
\end{tabular}

Source: http://db.auto.sohu.com/cxdata/ 